\title{
Copper deficiency in rodents alters dopamine $\beta$-mono-oxygenase activity, mRNA and protein level
}

\author{
Kyle T. Nelson and Joseph R. Prohaska* \\ Department of Biochemistry and Molecular Biology, University of Minnesota Medical School Duluth, 1035 University Drive, \\ Duluth, MN 55812, USA
}

(Received 30 July 2008 - Revised 3 October 2008 - Accepted 13 October 2008 - First published online 15 December 2008)

$\mathrm{Cu}$ is an essential cofactor for at least twelve mammalian enzymes including dopamine $\beta$-mono-oxygenase (DBM), which converts dopamine (DA) to noradrenaline (NA). Previous studies reported that certain $\mathrm{Cu}$-deficient $(\mathrm{Cu}-)$ rat tissues have lower NA and higher DA than $\mathrm{Cu}$-adequate $(\mathrm{Cu}+)$ tissues, suggesting that DBM function was impaired. However, in vitro studies suggested that DBM activity is higher in $\mathrm{Cu}-$ tissue. Experiments were conducted on adrenal glands (AG), medulla oblongata/pons (MO), vas deferens (VD) and heart (HT) from a single rat experiment to provide data to help clarify this puzzling contradiction. In vitro DBM activity assays showed $\mathrm{Cu}-$ samples had significantly higher activity than $\mathrm{Cu}+$ samples in both AG and MO, but not VD. Activity data were confirmed by Western immunoblots. Quantitative real-time PCR demonstrated higher DBM mRNA in $\mathrm{Cu}$ - tissues but unaltered levels of several other cuproenzymes and Cu-binding proteins. Previous pharmacological data implied that high DBM was associated with low NA. HPLC analyses confirmed that NA and DA levels in Cu- MO, VD and HT were significantly lower and higher, respectively, than in $\mathrm{Cu}+$ tissues. However, the NA content of AG was not statistically lower. Furthermore there was no correlation between higher DBM mRNA and lower NA in four $\mathrm{Cu}-$ tissues. Adequate dietary $\mathrm{Cu}$ is essential to support DBM function in vivo but additional studies are needed to determine the mechanism for increased DBM transcription associated with $\mathrm{Cu}$ deficiency.

Copper deficiency: Rats: Mice: Dopamine $\beta$-mono-oxygenase: Noradrenaline

$\mathrm{Cu}$ was recognised as an essential nutrient after careful laboratory studies in rats and field observations in sheep and cattle in the $1920 \mathrm{~s}$ and $1930 \mathrm{~s}^{(1)}$. As for other essential metals, $\mathrm{Cu}$ is required during perinatal development of the central nervous system $^{(2)}$. Cu's importance for brain development was further exemplified by research done on $\mathrm{Cu}$-deficient guinea-pigs where underdeveloped cerebella and hypomyelination were evident $^{(3)}$. In humans, the brain requirement for $\mathrm{Cu}$ is best illustrated by Menkes' disease, an X-linked inherited neurodegenerative disorder which was first connected with $\mathrm{Cu}$ deficiency in $1972^{(4)}$. The molecular reasons for the central nervous system phenotype accompanying $\mathrm{Cu}$ deficiency remain unknown.

Humans require $\mathrm{Cu}$ as an essential catalytic cofactor for approximately twelve mammalian cuproenzymes ${ }^{(5)}$. One is dopamine $\beta$-mono-oxygenase (EC 1.14.17.1; DBM) that catalyses the hydroxylation of dopamine (DA) to noradrenaline (NA) using $\mathrm{Cu}$, oxygen and ascorbic acid as additional substrates $^{(6)}$. DA and NA are important neurotransmitters required for the proper function of the brain. DBM is located in granulated vesicles of both sympathetic nerve terminals, adrenal medulla chromaffin cells, and noradrenergic and adrenergic neurons of brain ${ }^{(7)}$. The importance of DBM was demonstrated by the embryonic lethality of DBM knockout mice ${ }^{(8)}$. In vivo limitation of DBM following $\mathrm{Cu}$ deficiency was first demonstrated in heart tissue in $1967^{(9)}$. Normally NA synthesis is limited by tyrosine mono-oxygenase activity; however, under certain circumstances DBM can be rate limiting ${ }^{(10)}$.

The $\mathrm{Cu}-\mathrm{DBM}$ brain connection was concurrently made 2 years after the first report that Menkes' disease was associated with aberrant $\mathrm{Cu}$ metabolism. These studies in brindled mice, a genetic homologue of Menkes' disease, and in $\mathrm{Cu}$-deficient rats both reported lower brain NA and brain $\mathrm{Cu}^{(11,12)}$. More recently, it was observed that several brain regions had lower NA levels but higher DA levels in $\mathrm{Cu}$-deficient rats and mice compared with $\mathrm{Cu}$-adequate rodents ${ }^{(13,14)}$. Supported by these catecholamine results DBM activity was suggested to be lower in $\mathrm{Cu}$-deficient rodent brain.

Conversely, direct in vitro DBM activity assay of mutant mouse brain showed an increase in DBM activity ${ }^{(15,16)}$. Additionally, following dietary $\mathrm{Cu}$ deficiency in both rats and mice, higher brain DBM activity was reported ${ }^{(13,16)}$. Mutant blotchy mice, another mottled mutant, also exhibited higher DBM activity in adrenal glands ${ }^{(15)}$. Young male rats following perinatal $\mathrm{Cu}$ deficiency also demonstrated

Abbreviations: $\mathrm{CCS}, \mathrm{Cu}$ chaperone for superoxide dismutase; $\mathrm{Cu}+, \mathrm{Cu}$ adequate; $\mathrm{Cu}-, \mathrm{Cu}$ deficient; DA, dopamine; DBM, dopamine $\beta$-mono-oxygenase; $\mathrm{GAPDH}$, glyceraldehyde 3-phosphate dehydrogenase; NA, noradrenaline; PNGase, peptide:N-glycosidase; qRT, quantitative real-time.

* Corresponding author: Dr Joseph R. Prohaska, fax +1 218726 8014, email jprohask@d.umn.edu 
higher adrenal DBM activity ${ }^{(13)}$. DBM activity should be lower based on catecholamine levels; however, using enzyme assay, DBM activity was higher after $\mathrm{Cu}$ deficiency. Thus, a paradox exists.

Increased DBM activity following $\mathrm{Cu}$ deficiency is probably due to increased DBM protein abundance rather than augmented levels of inhibitors or lower levels of activators, but this has not been rigorously investigated. Adrenal DBM protein levels in older $\mathrm{Cu}$-deficient rats were higher than in $\mathrm{Cu}$-adequate rats ${ }^{(17)}$. Additionally, it was reported that adrenal mRNA for DBM was also increased following $\mathrm{Cu}$ deficiency $^{(18)}$. Medulla/pons DBM mRNA was higher in young $\mathrm{Cu}$-deficient females but not males based on Northern blot data, adding further to the confusion ${ }^{(18)}$. Thus it is still unknown whether an increase in DBM protein in brain of $\mathrm{Cu}$-deficient rats accompanies higher DBM activity.

The purpose of these experiments was to extend earlier observations on brain and adrenal DBM, measuring enzyme activity, mRNA, protein and catecholamine levels in a single perinatal $\mathrm{Cu}$ deficiency rat experiment. Additionally, a tissue innervated with sympathetic nerves, the vasa deferentia, was studied. Rat and mice adrenal NA levels are different when $\mathrm{Cu}$-deficient animals are compared with $\mathrm{Cu}$-adequate animals. It was not known if DBM protein levels changed in a similar manner; thus some analyses on $\mathrm{Cu}$-deficient mice were conducted. A second purpose of these studies was to test the hypothesis that depletion of NA was associated with increased transcription of DBM mRNA. Prior studies by several groups using reserpine to deplete catecholamines had made this prediction ${ }^{(19,20)}$.

\section{Experimental methods}

\section{Animal care and diets}

Holtzman rats and Hsd:ICR (CD-1) outbred albino mice were purchased commercially (Harlan Sprague-Dawley, Indianapolis, IN, USA). Rodents were maintained on $\mathrm{Cu}$-adequate $(\mathrm{Cu}+)$ or $\mathrm{Cu}$-deficient $(\mathrm{Cu}-)$ dietary treatment consisting of a Cu-deficient modified AIN-76A diet (Teklad Laboratories, Madison, WI, USA) that contained $0.36 \mathrm{mg} \mathrm{Cu} / \mathrm{kg}$ by analysis. All dams, minimum of five litters per treatment group, and offspring were fed the $\mathrm{Cu}-$ diet, but $\mathrm{Cu}+$ groups drank water supplemented with cupric sulfate $(20 \mathrm{mg} \mathrm{Cu} / \mathrm{l})$, and $\mathrm{Cu}-$ groups drank deionised water. $\mathrm{Cu}$ deprivation was started at embryonic day 7 for the rats and at birth (postnatal day 0) for mice. Litter size was culled to ten pups on postnatal day $2^{(21)}$. All animals were maintained on a $12 \mathrm{~h}$ light cycle (07.00 to 19.00 hours) at $24^{\circ} \mathrm{C}$ with $55 \%$ relative humidity and had free access to diet and water. The University of Minnesota Animal Care Committee approved all protocols.

Both male rats (postnatal day 24-postnatal day 26) and male mice (postnatal day 27-postnatal day 28) were weighed before anaesthetised with diethyl ether. The rodents were killed by decapitation. Medulla oblongata/pons, remainder of brain, liver samples, hearts, adrenal glands and vasa deferentia were harvested, weighed and processed for biochemical analysis or frozen in liquid $\mathrm{N}_{2}$ and stored at $-75^{\circ} \mathrm{C}$ until used.

\section{Biochemical analyses}

Selected tissues and diet were wet-digested with concentrated $\mathrm{HNO}_{3}$ (Trace Metal grade; Fisher Scientific, Pittsburgh, PA, USA). Digested material was suspended in $0 \cdot 1 \mathrm{M}-\mathrm{HNO}_{3}$ and analysed for total $\mathrm{Cu}$ content by flame atomic absorption spectroscopy (model 1100B; Perkin-Elmer, Norwalk, CT, USA). Protein levels of tissue samples were measured using a modified Lowry method ${ }^{(22)}$.

DBM activity was determined by a modified spectrophotometric method previously described ${ }^{(16)}$. Adrenal, medulla/ pons and vasa deferentia tissues were homogenised in 49,9 or 24 volumes of $5 \mathrm{mM}$-potassium phosphate ( $\mathrm{pH} 7 \cdot 0)$ containing $0.2 \%$ Triton $\mathrm{X}-100$. Conversion of tyramine to octopamine was determined as described elsewhere ${ }^{(23)}$

\section{Analysis of dopamine $\beta$-mono-oxygenase mRNA expression}

Total RNA was extracted from frozen samples using a TRI reagent ${ }^{\circledR}$ kit (Ambion, Austin, TX, USA), following manufacturer recommendations, including all optional steps. The purity of RNA was established spectrophotometrically and by RNA gels ${ }^{(18)}$. Contaminating DNA was removed using a DNA-free ${ }^{\mathrm{TM}}$ kit (Ambion), following manufacturer recommendations and cDNA was synthesised using Omniscript ${ }^{\circledR}$ Reverse Transcriptase (Qiagen ${ }^{\circledR}$, Valencia, CA, USA) and amplified with a SYBR Green I kit (Roche, Indianapolis, IN, USA).

Copy number of rat tissue mRNA of DBM, and glyceraldehyde 3-phosphate dehydrogenase (GAPDH) and/or ribosomal $18 \mathrm{~S}$, both used as controls, was determined by quantitative real-time (qRT)-PCR. Primers for DBM and GAPDH are listed in Table 1. Rat $18 \mathrm{~S}$ primer pairs were $5^{\prime} \mathrm{CTG}$ TGA TGC CCT TAG ATG TCC $3^{\prime}$ (forward) and $5^{\prime}$ GCT TAT GAC CCG CAC TTA CTG $3^{\prime}$ (reverse). Mass of the transcripts was determined by comparison with gel purified PCR product standards. Molecular weight was determined by entering full DNA sequence including the forward and reverse primers into a molecular-weight calculator to determine the complementary strand, in addition to the genes' molecular weight ${ }^{(24)}$. Dividing the mass of the gene transcript by its molecular weight and multiplying it by Avogadro's number calculated copy number.

\section{Dopamine $\beta$-mono-oxygenase antibody characterisation}

DBM antisera were developed in rabbits (Sigma Genosys, The Woodlands, TX, USA) against KLH-peptide, N-SEPPESPFPYHIPLD-C, corresponding to amino acid residues 43-57 and 44-58 in rats and mice, respectively. Anti-DBM antibody was affinity purified from final bleed serum using a SulfoLink ${ }^{\circledR}$ kit (Pierce, Rockford, IL, USA) according to manufacturer recommendations. The affinity purified DBM antibody was diluted 1:500 for Western blot analysis.

Antibody specificity was determined using two approaches, antigen blocking and mobility shift upon removal of carbohydrate. Blocking of the antibody was accomplished using Rat N-term DBM peptide (SEPPESPFPYHIPLD) with DBM primary antibody diluted 1:500 with either $12 \mu \mathrm{g}$ of peptide or $12 \mu \mathrm{g}$ of bovine serum albumin, as a control. Carbohydrate removal from DBM protein was accomplished 
Table 1. Relative mRNA expression of copper metabolism-related genes in medulla/pons of male rats aged $25 \mathrm{~d}$ (copy number per 1000 glyceraldehyde 3-phosphate dehydrogenase)†

(Mean values $(n 5)$ with their standard errors)

\begin{tabular}{|c|c|c|c|c|c|}
\hline \multirow[b]{2}{*}{ Gene } & \multirow[b]{2}{*}{ Primer pair } & \multicolumn{2}{|c|}{ Cu-adequate } & \multicolumn{2}{|c|}{ Cu-deficient } \\
\hline & & Mean & SEM & Mean & SEM \\
\hline DBM & $\begin{array}{l}\text { Forward: TGG AAT CTT GGA GGA GAT GTG CGT } \\
\text { Reverse: TGC CGA ACC GGT TTA CTA TGT GGA }\end{array}$ & $1 \cdot 83$ & 0.08 & $2 \cdot 76^{\star}$ & 0.30 \\
\hline CCS & $\begin{array}{l}\text { Forward: GAG TTG TCA GAG CTG CGT GCA C } \\
\text { Reverse: CCC TTG AGT ACA GCC TGC CTC }\end{array}$ & $37 \cdot 3$ & $3 \cdot 29$ & $36 \cdot 2$ & $6 \cdot 78$ \\
\hline COXI & $\begin{array}{l}\text { Forward: TCA CTG CCA GTA TTA GCA GCA GGT } \\
\text { Reverse: TCT GGG TGG CCG AAG AAT CAG AAT }\end{array}$ & 4814 & 555 & 5879 & 299 \\
\hline COX IV & $\begin{array}{l}\text { Forward: GCA CAT GGG AGT GTT GTG AAG AGT } \\
\text { Reverse: TTT CTC ATC CCT GGA AAG GCT GCT }\end{array}$ & 4222 & 583 & 5243 & 684 \\
\hline CTR1 & $\begin{array}{l}\text { Forward: GGA GAA ATG GCT GGA GCT TTT } \\
\text { Reverse: CGG GCT ATC TTG AGT CCT TCA }\end{array}$ & $9 \cdot 79$ & $2 \cdot 13$ & $13 \cdot 3$ & $1 \cdot 82$ \\
\hline PAM & $\begin{array}{l}\text { Forward: CAC TTC GAC ATG CCT CAT GAT } \\
\text { Reverse: TCA CAG GCA CCA AGA GT }\end{array}$ & 8.09 & 0.51 & 7.55 & $0 \cdot 16$ \\
\hline SOD1 & $\begin{array}{l}\text { Forward: GCG TCA TTC ACT TCG AGC AG } \\
\text { Reverse: ATA GGG AAT GTT TAT TGG GCA ATC }\end{array}$ & 521 & $35 \cdot 5$ & 493 & $30 \cdot 4$ \\
\hline
\end{tabular}

DBM, dopamine $\beta$-mono-oxygenase; CCS, Cu chaperone for superoxide dismutase; COX I, cytochrome c oxidase subunit 1; COX IV, cytochrome c oxidase subunit 4; CTR1, Cu transporter (SLC31A1); PAM, peptidylglycine $\alpha$-amidating mono-oxygenase; SOD1, Cu,Zn superoxide dismutase. * Mean value was significantly different from that of the Cu-adequate group $(P<0.05$; Student's $t$ test).

† Genes and their respective forward and reverse primers were designed for real-time PCR. Copy numbers of specific mRNA were determined by quantitative real-time PCR and compared in Cu-adequate and Cu-deficient rats.

using peptide:N-glycosidase (PNGase) F (New England BioLabs, Ipswich, MA, USA) according to manufacturer recommendations.

\section{Western blot analysis}

Samples for Western blot analysis of DBM, actin and $\mathrm{Cu}$ chaperone for superoxide dismutase (CCS) were prepared by homogenising frozen rat adrenal gland, medulla/pons and vasa deferentia, and mouse adrenals and vasa deferentia in 99, 9, 24, 39 or 9 volumes, respectively, of $50 \mathrm{~mm}$-potassium phosphate buffer ( $\mathrm{pH} 7 \cdot 0$ ) containing $0.2 \%$ Triton X-100 and protease inhibitors (Protease Inhibitor Cocktail; Sigma Chemical, St Louis, MO, USA). Homogenates were centrifuged at $10000 \mathrm{~g}$ for $10 \mathrm{~min}$ at $4^{\circ} \mathrm{C}$ and supernatant fractions were saved for analysis at $-75^{\circ} \mathrm{C}$. Fractionation was completed on $10 \%$ SDS-PAGE gels. Transfer of protein to $0.2 \mu \mathrm{m}$ nitrocellulose membranes and processing for immunoblotting was described previously ${ }^{(17)}$. Membranes were stained with Ponceau S (Sigma Chemical) to verify equal protein loading.

Protein levels of CCS were evaluated using affinity purified rabbit anti-hCCS characterised previously, at a 1:500 dilution $^{(25)}$. Membranes were also probed for actin to verify equal loading of protein. Chemiluminescence was captured using high-speed blue X-ray film (Lake Superior X Ray Inc., Duluth, MN, USA) and densitometry was carried out using a Kodak Image Station 2000M and Molecular Imaging Software (version 4.0.4; Kodak, New Haven, CT, USA).

\section{Catecholamine analysis}

Catecholamines were extracted from tissues by homogenising with nine volumes of $0.05 \mathrm{M}-\mathrm{HClO}_{4}$ containing $0.3 \mu \mathrm{M}-3,4-$ dihydroxybenzylamine ${ }^{(26)}$. Catecholamines were eluted from alumina with $200 \mu \mathrm{l}$ of a 60:40 mixture of 0.2 M-acetic acid

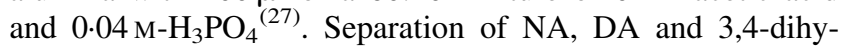
droxybenzylamine was accomplished using reverse-phase ion pairing HPLC with electrochemical detection using a mobile phase of $0.5 \mathrm{~mm}$-1-octanesulfonic acid, $0.1 \mathrm{~mm}$ EDTA and $0 \cdot 1 \mathrm{M}-\mathrm{KH}_{2} \mathrm{PO}_{4}$ with $6 \cdot 5-8 \%$ methanol. The $\mathrm{pH}$ was adjusted to 3.0 with $0.1 \mathrm{M}$-phosphoric acid. Samples were separated on a $3.2 \times 15 \mathrm{~mm}$ cartridge guard column and a $4.6 \times 250 \mathrm{~mm}$ analytical column (ODS-II $5 \mu \mathrm{m}$; Regis, Morton Grove, IL, USA). Output was recorded and peaks were integrated using Peak Simple Software (Chrom Tech, Inc., Apple Valley, MN, USA) ${ }^{(21)}$.

\section{Statistical analysis}

Mean values with their standard errors were calculated. Student's unpaired two-tailed $t$ test was used to compare data between the two dietary treatments, $\alpha=0.05$ and $\alpha=0.01$. Variance equality was evaluated by the $F$ test. All data were processed using Microsoft Excel $^{\text {TM }}$ (Redmond, WA, USA). Immunoblot data normalisation was accomplished by assigning a value of 1.0 to the mean pixel density of the $\mathrm{Cu}+$ samples. All individual $\mathrm{Cu}+$ and $\mathrm{Cu}-$ density values were then recalculated before graphing for ease of comparison. Correlation analysis for scatter plot was calculated using Excel ${ }^{\mathrm{TM}}$ and a Pearson product moment correlation coefficient table of critical values, for two-tailed test and $\alpha=0 \cdot 05$.

\section{Results}

\section{Rodent biochemical characteristics}

Following perinatal $\mathrm{Cu}$ deficiency, $\mathrm{Cu}$ status in the rat experiment was analysed by evaluating a number of characteristics: body weight, cardiac hypertrophy (heart:body weight ratio), brain $\mathrm{Cu}$ and liver $\mathrm{Cu}$ (Table 2). All of the characteristics 
Table 2. Characteristics of male Holtzman rats (aged 24-26d) and male CD-1 mice (aged 27-28d) following copper deficiency (Mean values with their standard errors for five to fifteen animals)

\begin{tabular}{|c|c|c|c|c|c|c|c|c|c|}
\hline \multirow[b]{2}{*}{ Species } & \multirow[b]{2}{*}{ Diet } & \multicolumn{2}{|c|}{ Body weight (g) } & \multicolumn{2}{|c|}{$\begin{array}{l}\text { Heart:body weight } \\
\text { ratio }(\mathrm{mg} / \mathrm{g})\end{array}$} & \multicolumn{2}{|c|}{ Brain Cu $(\mu \mathrm{g} / \mathrm{g})$} & \multicolumn{2}{|c|}{ Liver Cu $(\mu \mathrm{g} / \mathrm{g})$} \\
\hline & & Mean & SEM & Mean & SEM & Mean & SEM & Mean & SEM \\
\hline Rat & $\mathrm{Cu}+$ & 83.3 & 1.8 & $5 \cdot 11$ & 0.14 & $2 \cdot 30$ & 0.06 & $6 \cdot 51$ & 0.55 \\
\hline Rat & $\mathrm{Cu}-$ & $61.9^{\star \star}$ & $1 \cdot 1$ & $12 \cdot 8^{\star \star}$ & 0.64 & $0.44^{\star \star}$ & 0.04 & $0.42^{\star \star}$ & 0.03 \\
\hline Mouse & $\mathrm{Cu}+$ & $21 \cdot 6$ & $1 \cdot 1$ & $5 \cdot 30$ & 0.11 & 2.99 & 0.12 & $4 \cdot 28$ & 0.29 \\
\hline Mouse & $\mathrm{Cu}-$ & $19 \cdot 3$ & $1 \cdot 1$ & $8 \cdot 17^{\star \star}$ & 0.47 & $0.70^{\star *}$ & 0.06 & $1 \cdot 22^{\star *}$ & 0.04 \\
\hline
\end{tabular}

$\mathrm{Cu}+, \mathrm{Cu}$-adequate; $\mathrm{Cu}-, \mathrm{Cu}$-deficient.

${ }^{* *}$ Mean value was significantly different from that of the $\mathrm{Cu}+$ animals of the same species $(P<0.01$; Student's $t$ test $)$.

showed a statistical difference between the $\mathrm{Cu}-$ and $\mathrm{Cu}+$ animals. Body weights in the $\mathrm{Cu}-$ rats were significantly lower than in the $\mathrm{Cu}+$ rats. Cardiac hypertrophy occurred in $\mathrm{Cu}-$ rats compared with $\mathrm{Cu}+$ rats, as evident by the 2.5 times greater heart:body weight ratio. $\mathrm{Cu}-$ rats had a major reduction in brain $\mathrm{Cu}$ compared with $\mathrm{Cu}+$ rats $(81 \%)$ consistent with neuronal $\mathrm{Cu}$ deficiency. $\mathrm{Cu}$ deficiency in a peripheral tissue was evident as well. $\mathrm{Cu}-$ rats showed a severe reduction in liver $\mathrm{Cu}$ compared with $\mathrm{Cu}+$ rats $(94 \%)$. These four characteristics demonstrate that the dietary model in the rats studied was successful in achieving rats of two different $\mathrm{Cu}$ states. The same four characteristics were measured in the mouse experiment at postnatal day 27-postnatal day 28 (Table 2). Results were similar to those of the rat, except that there was no change in body weight due to $\mathrm{Cu}$ deficiency. Compared with $\mathrm{Cu}+$ mice, $\mathrm{Cu}-$ mice had a heart:body weight ratio 1.5 times higher, a $77 \%$ reduction in brain $\mathrm{Cu}$ and a $71 \%$ reduction in liver $\mathrm{Cu}$.

\section{Dopamine $\beta$-mono-oxygenase antibody specificity}

Two experiments were performed to determine DBM antibody specificity. Affinity purified DBM antibody detected a single immunoreactive band of approximately $75 \mathrm{kDa}$ in adrenal glands from rats and mice, similar to the size previously characterised $^{(28)}$. The antibody detected multiple immunoreactive bands for medulla oblongata/pons, all smaller in size than $75 \mathrm{kDa}$ (Fig. 1). In experiment 1, two Western blots with adrenal glands, medulla oblongata/pons, and liver, as a negative control, were performed: one in which the antibody was treated with bovine serum albumin and one treated

(a)

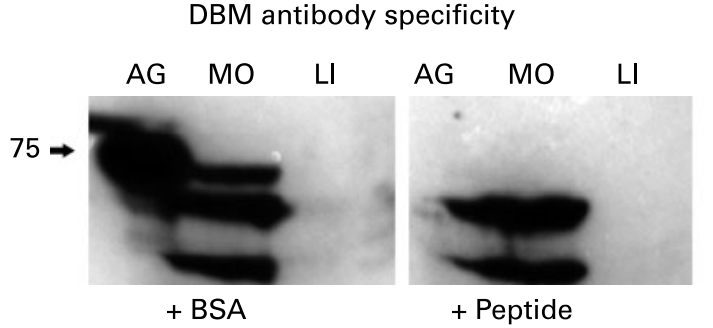

with DBM blocking peptide (Fig. 1 (a)). Antibody treated with bovine serum albumin results in a single adrenal gland band $(75 \mathrm{kDa})$ and multiple medulla oblongata/pons bands. The lane loaded with liver had no immunoreactive band. In contrast, the blot treated with DBM peptide clearly shows that the band at $75 \mathrm{kDa}$ in the adrenal gland lane and the slightly smaller band in the medulla oblongata/pons lane are blocked by DBM peptide.

In experiment 2, a Western blot was performed with adrenal gland and medulla oblongata/pons samples. $\mathrm{Cu}-$ samples indicated by $(-)$ and $\mathrm{Cu}+$ samples $(+)$ above the blot were compared (Fig. 1 (b)). Samples before loading were either treated with PNGase $(+)$ or just buffer $(-)$. The adrenal gland sample not treated with PNGase displayed the usual immunoreactive band detected at $75 \mathrm{kDa}$. In contrast, the adrenal gland sample treated with PNGase migrated further, due to the removal of carbohydrate from DBM. Both the $\mathrm{Cu}-$ and $\mathrm{Cu}+$ medulla oblongata/pons samples yielded a pattern approximately the same as before (Fig. 1 (a)), when not treated with PNGase (Fig. 1 (b)). The upper band in both $\mathrm{Cu}-$ and $\mathrm{Cu}+$ medulla oblongata/pons samples disappeared when treated with PNGase. The second band was more dense when treated with PNGase. This is consistent with the removal of carbohydrates from DBM and a similar migration shift of DBM seen for adrenal glands.

\section{Adrenal gland analysis}

Adrenal gland homogenates from postnatal day 24 male rats were used to determine DBM activity which was greatly influ- (b)

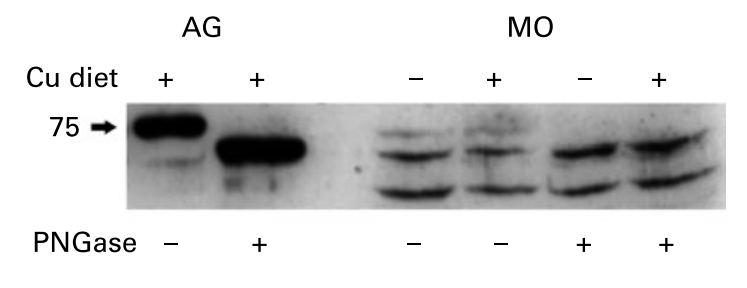

Fig. 1. Dopamine $\beta$-mono-oxygenase (DBM) antibody characterisation. (a) Blocking of antibody with DBM peptide or bovine serum albumin (BSA) was analysed by Western blot of adrenal glands (AG) and medulla oblongata/pons (MO). Liver (LI) was used as a negative control. (b) Cu-adequate (+) or Cu-deficient (-) samples were either treated with peptide:N-glycosidase (PNGase) $(+)$ or buffer $(-)$ and were analysed by Western blot. DBM bands in both the AG and MO lanes migrated further down the blot when treated with the PNGase, consistent with carbohydrate removal. 
enced by $\mathrm{Cu}$ deficiency. Activity, in vitro, of $\mathrm{DBM}$ from $\mathrm{Cu}-$ adrenal gland samples was 2.4-fold higher than that of $\mathrm{Cu}+$ samples (Fig. 2 (a)).

Total RNA from adrenal glands was isolated from postnatal day 25 male rats of both treatment groups and qRT-PCR was performed to determine the copy numbers of DBM and GAPDH, an expression control. The number of copies of DBM transcript per 1000 copies of GAPDH transcript was significantly higher, 0.7-fold, in $\mathrm{Cu}-$ compared with $\mathrm{Cu}+$ samples (Fig. 2 (b)). GAPDH copy number was not affected by diet.

To extend data for DBM activity and transcript levels, adrenal gland DBM protein abundance of postnatal day 24 male rats was measured by Western immunoblot. The DBM immunoreactive band is clearly detected at $75 \mathrm{kDa}$. It was apparent that DBM protein abundance was markedly higher in $\mathrm{Cu}-$ than the $\mathrm{Cu}+$ samples. $\mathrm{Cu}$ status was determined by measuring CCS protein abundance. CCS abundance has been shown to increase when $\mathrm{Cu}$ is limiting ${ }^{(29)}$. In adrenal glands CCS abundance was markedly higher in $\mathrm{Cu}-$ than $\mathrm{Cu}+$ tissue (Fig. 2 (c)). Actin, a loading control, was not changed by treatment (Fig. 2 (c)). Mean DBM density of $\mathrm{Cu}-$ adrenal glands was 1.7-fold higher than that of the $\mathrm{Cu}+$ samples (Fig. 2 (d)). Mean CCS density in $\mathrm{Cu}-$ adrenal glands was even higher, a 3·6-fold difference (Fig. 2 (d)).

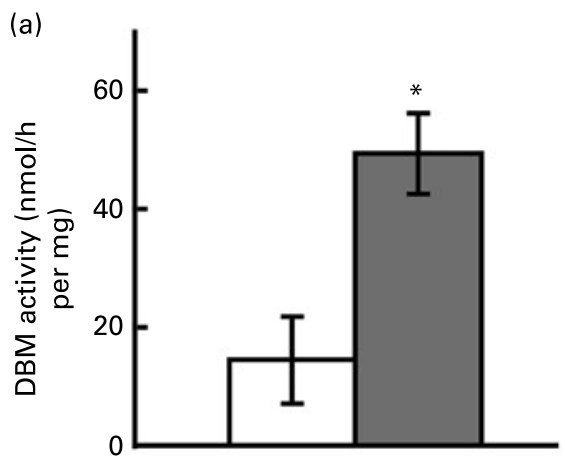

(c)

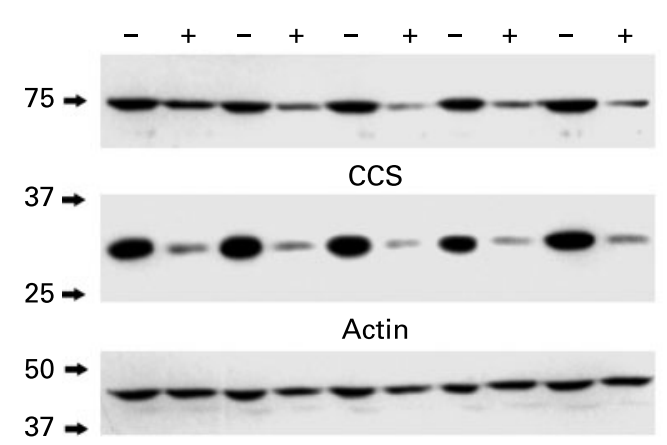

\section{Medulla oblongata/pons analysis}

DBM activity in medulla oblongata/pons from postnatal day 24 male rats was greatly influenced by $\mathrm{Cu}$ deficiency and was 0.9fold higher in $\mathrm{Cu}-$ medulla oblongata/pons than $\mathrm{Cu}+$ medulla oblongata/pons (Fig. 3 (a)). Specific activity in medulla oblongata/pons was much lower than for adrenal glands.

Total RNA from medulla oblongata/pons was isolated from postnatal day 25 male rats of both treatment groups and qRTPCR was performed to determine the copy numbers of both DBM and GAPDH. DBM transcript abundance, per 1000 copies of GAPDH, was significantly higher, 0.5-fold, in $\mathrm{Cu}-$ compared with $\mathrm{Cu}+$ rats (Fig. 3 (b)). GAPDH copy number was not different between the two groups. There was very low expression of DBM mRNA in medulla oblongata/pons compared with adrenal glands. In $\mathrm{Cu}+$ rats, abundance in medulla oblongata/pons was less than 2 per 1000 GAPDH, whereas in adrenal glands, abundance exceeded 250. This fact made Western immunoblot detection of medulla oblongata/pons DBM very challenging as was shown in Fig. 1.

Medulla oblongata/pons DBM protein abundance of postnatal day 26 male rats was measured by Western immunoblot and the immunoreactive DBM band was detected slightly below the $75 \mathrm{kDa}$ marker. It was apparent that both DBM and $\mathrm{CCS}$ protein abundance was higher in $\mathrm{Cu}-$ than $\mathrm{Cu}+$

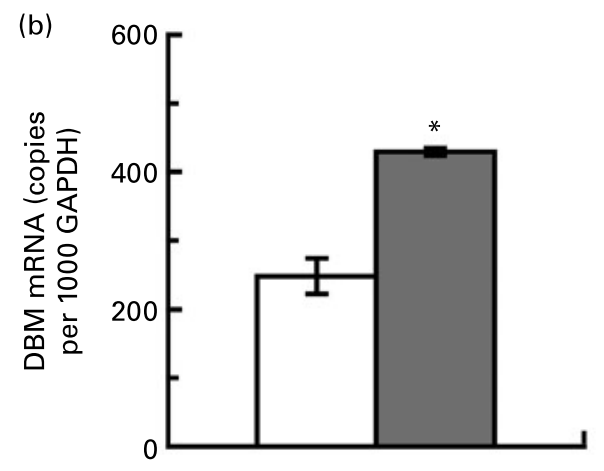

(d)

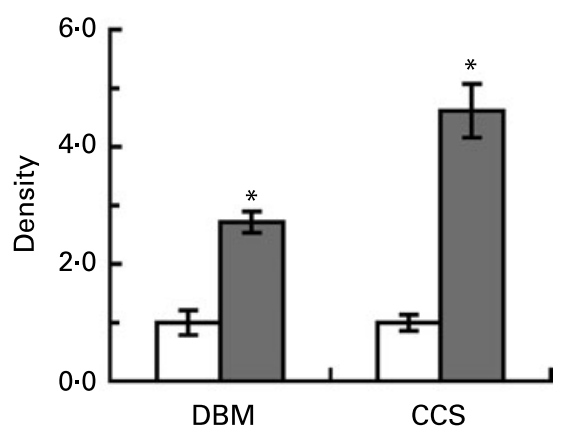

Fig. 2. Adrenal gland (AG) dopamine $\beta$-mono-oxygenase (DBM) evaluation. (a) DBM activity of postnatal day 24 male Holtzman rats following perinatal Cu deficiency. ( $\square$ ), Cu-adequate samples; ( $\square$ ), Cu-deficient samples. (b) Copy number of DBM and glyceraldehyde 3-phosphate dehydrogenase (GAPDH) mRNA was determined by using quantitative real-time PCR from postnatal day 25 male rats. (c) DBM protein abundance (15 $\mu$ g) in postnatal day 24 male rats was analysed by Western blot. Cu status was evaluated by the marker Cu chaperone for superoxide dismutase (CCS). Actin was used as a loading control. (d) Densitometry means were determined for $\mathrm{Cu}$-adequate and Cu-deficient AG samples. DBM protein levels in Cu-deficient samples were significantly higher compared with Cu-adequate samples. Values are means $(n 5)$, with standard errors represented by vertical bars. * Mean value was significantly different from that of the Cu-adequate rats $(P<0.05$; Student's $t$ test $)$. 
(a)

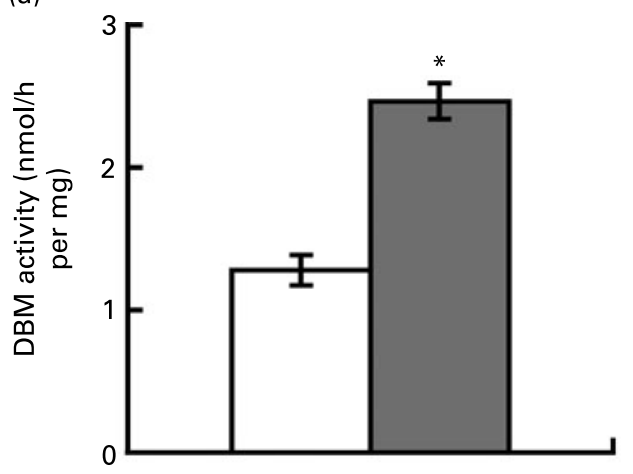

(c)

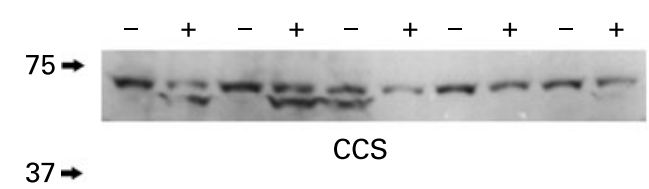

(b)

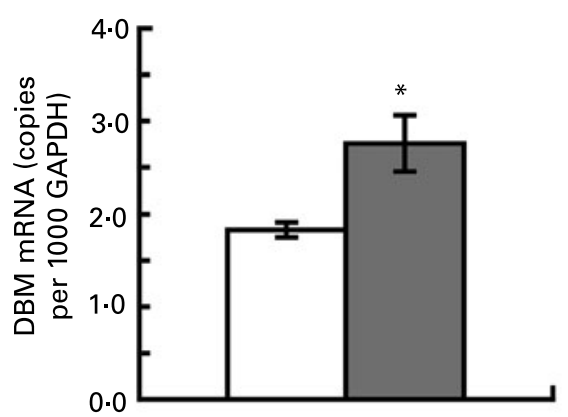

(d)

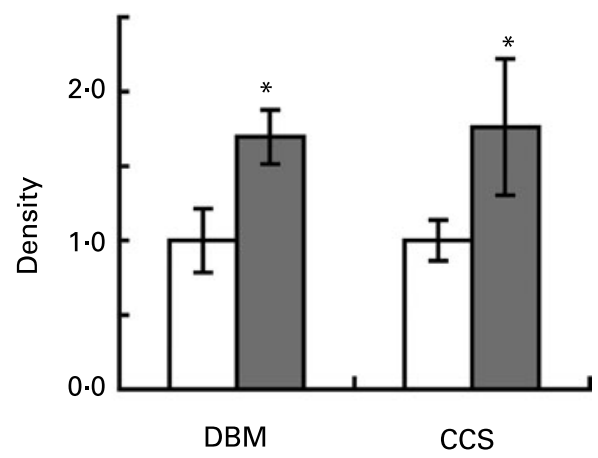

Fig. 3. Medulla oblongata/pons (MO) dopamine $\beta$-mono-oxygenase (DBM) evaluation. (a) DBM activity of postnatal day 24 male Holtzman rats following perinatal Cu deficiency. $(\square)$, Cu-adequate samples; ( $\square$ ), Cu-deficient samples. (b) Copy number of DBM and glyceraldehyde 3-phosphate dehydrogenase (GAPDH) mRNA was determined by using quantitative real-time PCR from postnatal day 25 male rats. (c) DBM protein abundance $(75 \mu \mathrm{g})$ in postnatal day 26 male rats was analysed by Western blot. Cu status was evaluated by the marker $\mathrm{Cu}$ chaperone for superoxide dismutase (CCS). Actin was used as a loading control. (d) Densitometry means were determined for $\mathrm{Cu}$-adequate and Cu-deficient MO samples. DBM protein levels in Cu-deficient samples were significantly higher compared with $\mathrm{Cu}$-adequate samples. Values are means $(n 5)$, with standard errors represented by vertical bars. ${ }^{*}$ Mean value was significantly different from that of the Cuadequate rats $(P<0.05$; Student's $t$ test $)$.

samples (Fig. 3 (c)). Actin was not changed by treatment (Fig. 3 (c)). The augmentation of DBM in $\mathrm{Cu}-$ medulla oblongata/pons tissue was not as high as in adrenal glands. The mean DBM density of $\mathrm{Cu}-$ samples was 0.7-fold higher than that of the $\mathrm{Cu}+$ samples (Fig. 3 (d)). The mean $\mathrm{CCS}$ density in $\mathrm{Cu}-$ medulla oblongata/pons samples displayed a similar $0 \cdot 8$-fold increase.

\section{Vasa deferentia analysis}

DBM activity measured in homogenates from vas deferens from postnatal day 25 male rats was not statistically influenced by $\mathrm{Cu}$ deficiency (Fig. 4 (a)).

However, surprisingly the number of copies of DBM transcript per 1000 copies of GAPDH transcript was significantly higher in $\mathrm{Cu}-$ compared with $\mathrm{Cu}+$ vas deferens (Fig. 4 (b)). The $\mathrm{Cu}-$ samples were 2.4-fold higher than the $\mathrm{Cu}+$ samples. The GAPDH copy number was not different between the two groups. Relative mRNA expression of $\mathrm{DBM}$ in $\mathrm{Cu}+$ samples in vas deferens was similar to medulla oblongata/pons.

DBM activity in the vas deferens suggested that there was no enhancement in DBM protein abundance, in contrast to adrenal glands and medulla oblongata/pons, but DBM transcript data suggested otherwise. Thus, vas deferens DBM protein abundance of postnatal day 24 male rats was measured by Western immunoblot and, like DBM activity, was not statistically higher in $\mathrm{Cu}$ - samples. Vas deferens actin levels were not altered by diet (Fig. 4 (c)). Mean CCS density did reveal a modest and statistically significant $0 \cdot 4$-fold higher abundance in $\mathrm{Cu}-$ compared with $\mathrm{Cu}+$ vas deferens extracts consistent with marginal $\mathrm{Cu}$ deficiency in vas deferens (Fig. 4 (d)).

\section{Mouse analysis}

Mouse adrenal gland and vas deferens DBM protein abundance was analysed to determine if mice respond similarly to rats when subjected to $\mathrm{Cu}$ deficiency. Adrenal gland tissue was from postnatal day 27 male mice and vas deferens tissue from postnatal day 28 male mice. The two tissues were evaluated separately. It was apparent that both DBM and CCS protein abundance in adrenal glands was higher in the $\mathrm{Cu}-$ samples compared with $\mathrm{Cu}+$ samples (Fig. 5 (a)). Mouse vas deferens DBM protein was detected in $\mathrm{Cu}-$ samples but not in $\mathrm{Cu}+$ samples (Fig. 5 (b)). CCS protein was clearly more abundant in $\mathrm{Cu}-$ vas deferens samples, similar to 
(a)

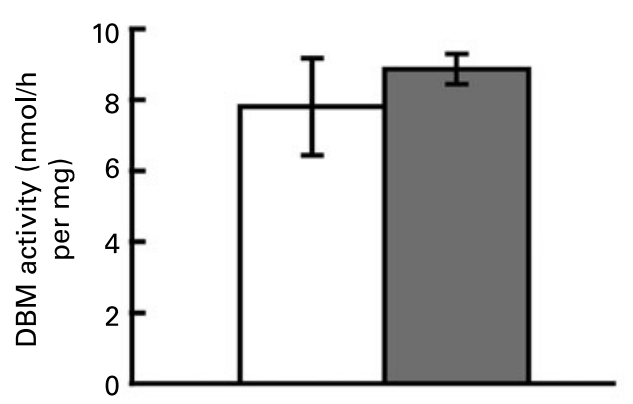

(c)
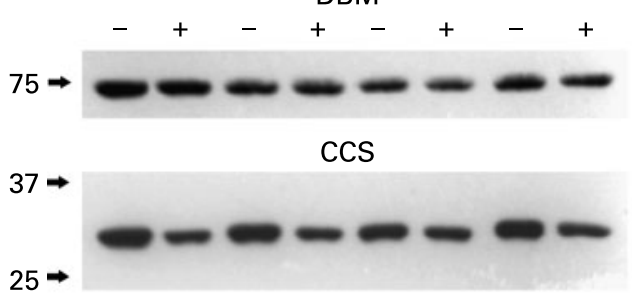

Actin

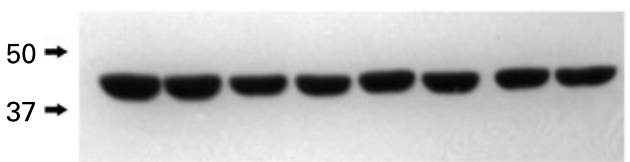

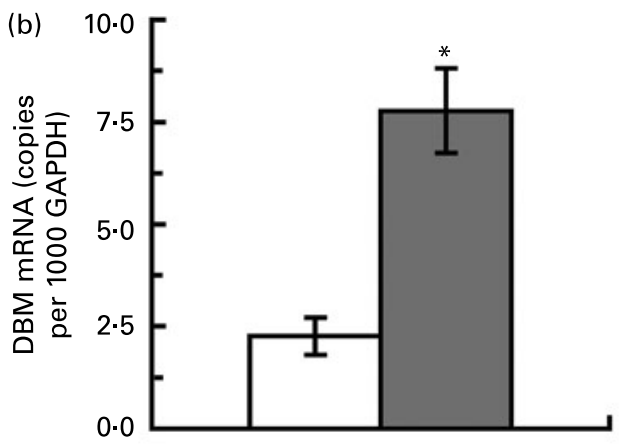

(d)

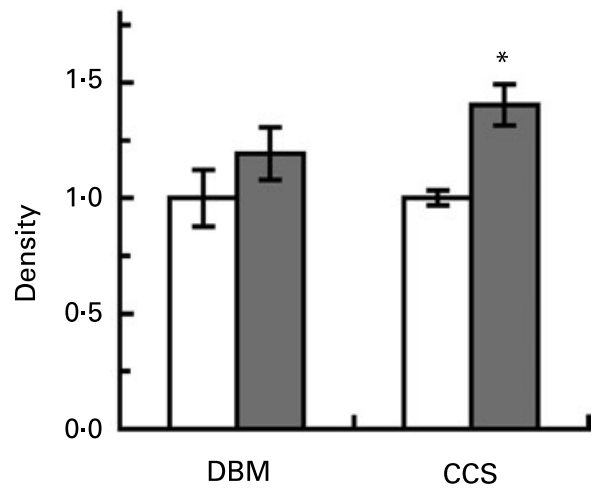

Fig. 4. Vas deferens dopamine $\beta$-mono-oxygenase (DBM) evaluation. (a) DBM activity of postnatal day 25 (P25) male Holtzman rats following perinatal Cu deficiency. ( $\square$ ), Cu-adequate samples; ( $\square$ ), Cu-deficient samples. (b) Copy number of DBM and glyceraldehyde 3-phosphate dehydrogenase (GAPDH) mRNA was determined by quantitative real-time PCR in P25 male rats. (c) DBM vas deferens protein abundance $(15 \mu \mathrm{g})$ in postnatal day 24 male rats was analysed by Western blot. Cu status was evaluated by the marker Cu chaperone for superoxide dismutase (CCS). Actin was used as a loading control. (d) Densitometry means were determined for $\mathrm{Cu}$-adequate and $\mathrm{Cu}$-deficient vas deferens samples. DBM protein levels in $\mathrm{Cu}$-deficient samples were not different from those of $\mathrm{Cu}$ adequate samples. Values are means $(n 4)$, with standard errors represented by vertical bars. ${ }^{*}$ Mean value was significantly different from that of the Cu-adequate rats $(P<0.05$; Student's $t$ test $)$.

rat tissue. Ponceau S stain was used as a loading control in mouse tissue because actin data were unreliable in mice. Consistent with immunoblot data, mean adrenal gland DBM activity was higher in $\mathrm{Cu}-$ samples (129 (SEM 19) nmol/h per $\mathrm{mg}$ ) compared with $\mathrm{Cu}+$ samples $(76 \cdot 3$ (SEM 7.3) nmol/ $\mathrm{h}$ per $\mathrm{mg}$ ) for mouse adrenal glands $(n 4 ; P<0 \cdot 05)$.

(a)

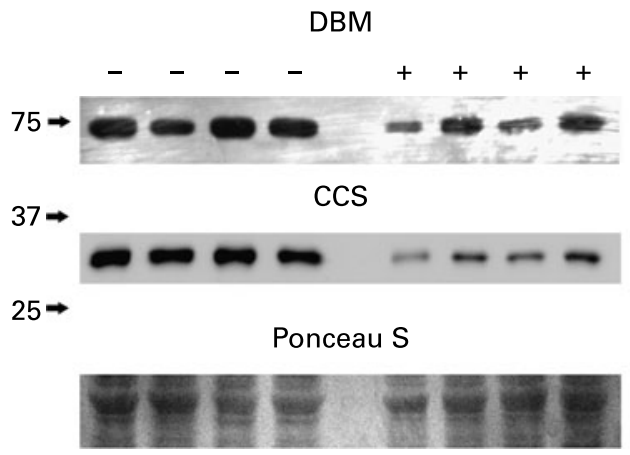

\section{Expression of copper-related genes}

Copper-related genes in addition to DBM were studied to determine if the DBM transcription abundance enhancement was unique. Medulla oblongata/pons relative mRNA expression in postnatal day 25 male rats was determined for

(b)
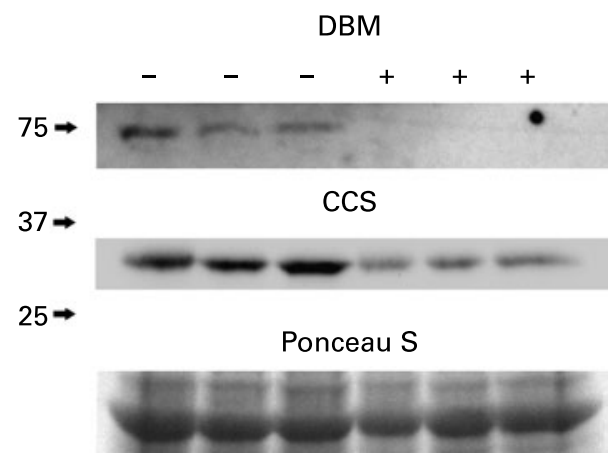

Fig. 5. Evaluation of mouse dopamine $\beta$-mono-oxygenase (DBM). (a) DBM protein abundance of adrenal glands of postnatal day 27 male mice following Cu deficiency was analysed by Western blot. Cu chaperone for superoxide dismutase (CCS) was used to confirm Cu deficiency. Ponceau S stain was used as a loading control; $30 \mu \mathrm{g}$ protein was loaded. Cu-deficient (-) samples had significantly higher abundance of both DBM and CCS protein compared with Cu-adequate (+) samples. (b) DBM and CCS abundance in vas deferens of postnatal day 28 male mice following Cu deficiency was analysed by Western blot. Ponceau S stain was used as a loading control; $50 \mu \mathrm{g}$ protein was loaded. Cu-deficient $(-)$ samples had significantly higher levels of both DBM and CCS protein compared with Cu-adequate $(+)$ samples. 
the following genes: DBM, CCS, cytochrome c oxidase subunit 1 (COX I), cytochrome c oxidase subunit 4 (COX IV), $\mathrm{Cu}$ transporter (SLC31A1) (CTR1), peptidylglycine $\alpha$-amidating mono-oxygenase (PAM) and $\mathrm{Cu}, \mathrm{Zn}$ superoxide dismutase (EC 1.15.1.1) (SOD1) using primer pairs for qRT-PCR (Table 1). Only DBM showed a statistical difference between $\mathrm{Cu}-$ and $\mathrm{Cu}+$ samples. Even though protein abundance for the CCS was elevated in $\mathrm{Cu}$ deficiency (Fig. 3 (c)), CCS mRNA was not altered by diet. The abundance of DBM mRNA in medulla oblongata/pons was very low compared with cuproenzymes SOD1 or cytochrome c oxidase, and similar to PAM.

\section{Catecholamine analysis}

Catecholamines were extracted from postnatal day 26 male rat adrenal glands, medulla oblongata/pons and vas deferens, and from P24 male rat heart. HPLC analyses demonstrated that diet did not have a significant effect on total NA in adrenal glands. However, total DA and DA:NA ratio $(100 \times \mathrm{DA} /$ NA) were significantly higher in $\mathrm{Cu}-$ compared with $\mathrm{Cu}+$ rats (Fig. 6 (a)), a 2-fold increase for both. $\mathrm{Cu}$ deficiency also had a significant effect in medulla oblongata/pons. NA concentration was lower by $25 \%$ in $\mathrm{Cu}-$ compared with $\mathrm{Cu}+$ tissue and DA concentration and DA:NA ratio was higher by $1 \cdot 2$-fold and $2 \cdot 2$-fold, respectively, in $\mathrm{Cu}-$ compared with $\mathrm{Cu}+$ medulla oblongata/pons (Fig. 6 (b)). $\mathrm{Cu}$ deficiency also had a significant effect in vas deferens and heart. Total NA in vas deferens was lower by $29 \%$ in $\mathrm{Cu}-$ compared with $\mathrm{Cu}+$ rats and DA concentration and DA:NA ratio were elevated by approximately $0 \cdot 6$-fold and $1 \cdot 1$-fold, respectively, in $\mathrm{Cu}-$ compared with $\mathrm{Cu}+$ tissue (Fig. 6 (c)). Total NA in heart was lower by $64 \%$ in $\mathrm{Cu}-$ compared with $\mathrm{Cu}+$ rats and DA concentration and DA:NA ratio were markedly higher by 15 -fold and 48-fold, respectively, in $\mathrm{Cu}-$ compared with $\mathrm{Cu}+$ rats (Fig. 6 (d)). Collectively, these catecholamine data suggest that $\mathrm{Cu}$ deficiency limits DBM activity in vivo.

\section{Correlation of dopamine $\beta$-mono-oxygenase $m R N A$ expression $v$. noradrenaline concentration}

To compare DBM mRNA elevation with NA depletion in tissues, heart DBM copy number was first determined by qRT-PCR. There was no statistical difference between DBM copy number in $\mathrm{Cu}-$ and $\mathrm{Cu}+$ heart samples when normalised to 1000 copies of GAPDH (Fig. 7 (a)). However, unlike other tissues studied, GAPDH copy number was slightly higher in $\mathrm{Cu}-$ than $\mathrm{Cu}+$ heart. Thus, $18 \mathrm{~S}$ ribosomal RNA abundance was determined and when using an average of both loading controls, GAPDH and $18 \mathrm{~S}$, there was a modest increase $(0 \cdot 4$-fold $)$ in DBM copy number $(P<0 \cdot 05)$. DBM mRNA abundance of heart was the lowest of all tissues studied, even lower than medulla oblongata/pons (Fig. 3 (b)).

DBM mRNA elevation may be due to NA reduction; therefore, DBM mRNA elevation in four $\mathrm{Cu}-$ tissue samples was

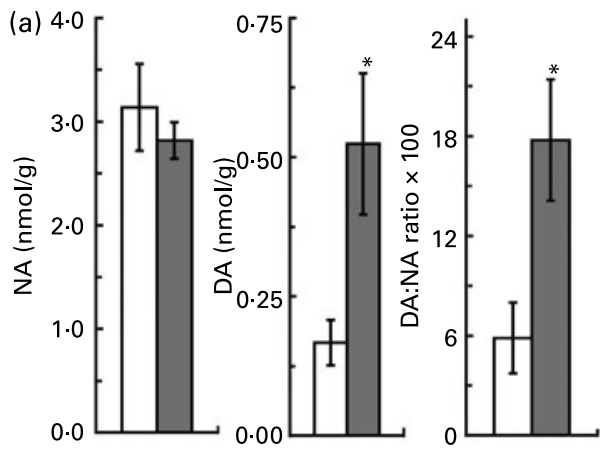

(b)

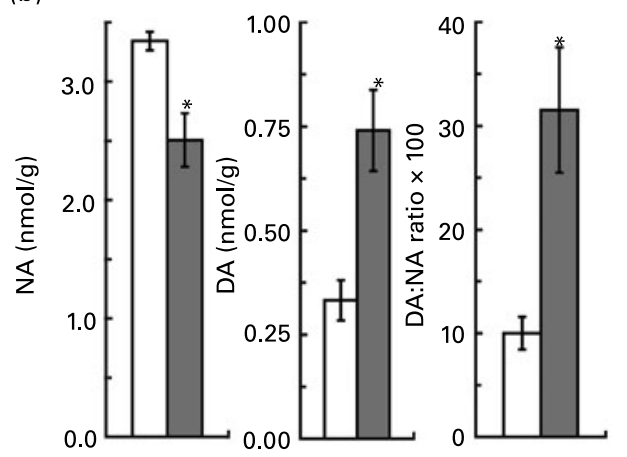

(c)

(d)
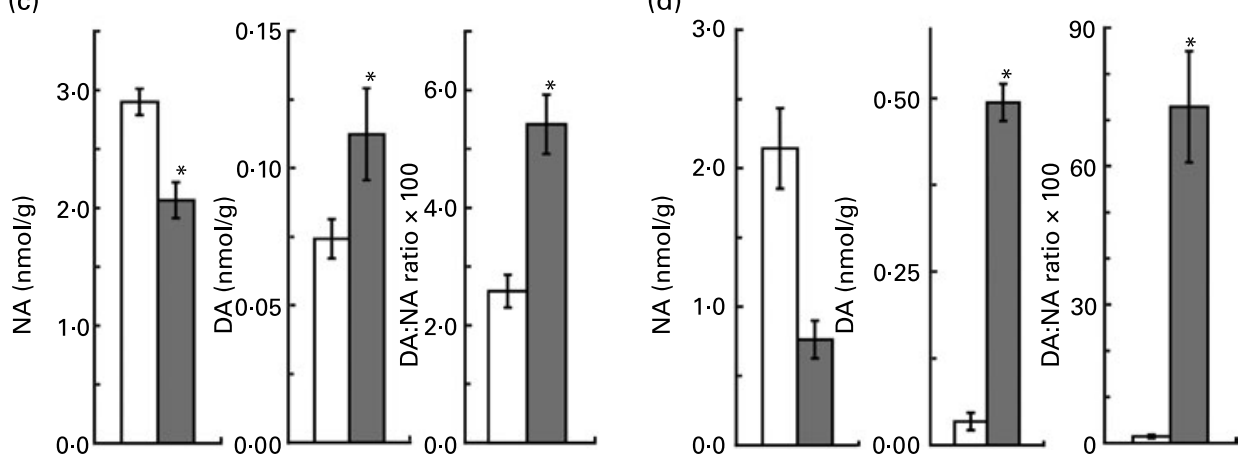

Fig. 6. Measurement of rat catecholamine concentrations by HPLC with electrochemical detection. Noradrenaline (NA) and dopamine (DA) levels were determined following perinatal $\mathrm{Cu}$ deficiency in male rat adrenal glands (a), medulla oblongata/pons (b), vasa deferentia (c) and heart (d). For adrenal glands, medulla oblongata/pons and vasa deferentia, rats at postnatal day 26 were sampled. For heart, rats at postnatal day 24 were sampled. ( $\square$ ), Cu-adequate samples; ( $\square$ ), Cu-deficient samples. Values are means $(n 3-5)$, with standard errors represented by vertical bars. * Mean value was significantly different from that of the Cu-adequate rats $(P<0.05$; Student's $t$ test). 

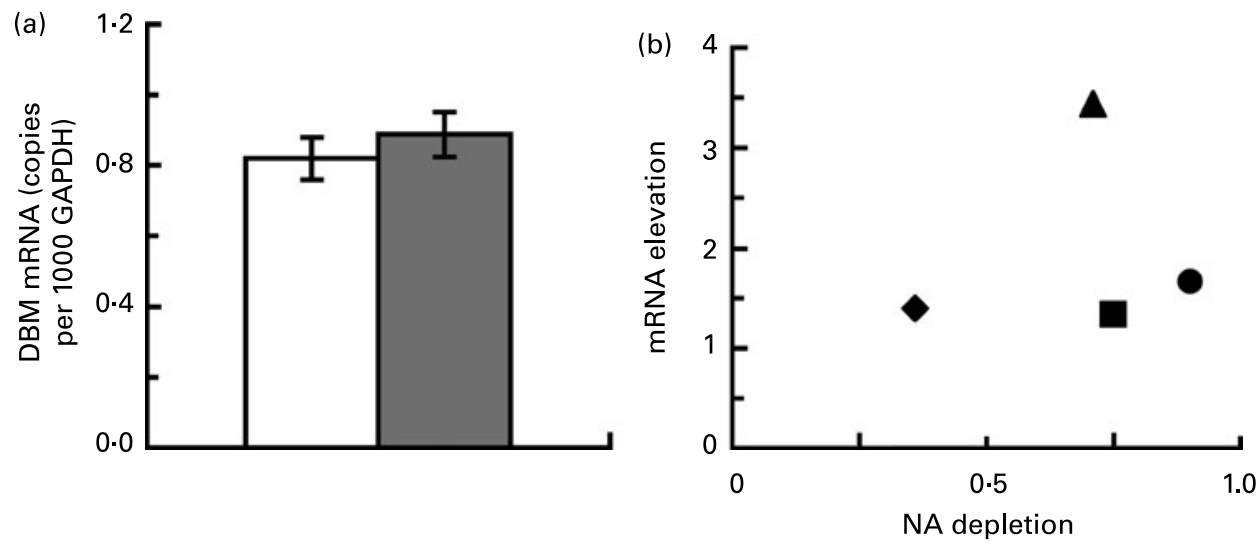

Fig. 7. Abundance of dopamine $\beta$-mono-oxygenase (DBM) mRNA in rat heart and relationship of the enhancement of DBM mRNA with noradrenaline (NA) deficit in Cu-deficient tissues. (a) Copy number of DBM and glyceraldehyde 3-phosphate dehydrogenase (GAPDH) mRNA was determined using quantitative real-time PCR in the heart of postnatal day 26 male rats. DBM copy number/1000 GAPDH means were compared in Cu-adequate $(\square)$ and Cu-deficient $(\square)$ heart samples. Values are means $(n 3)$, with standard errors represented by vertical bars. No significant differences were detected. (b) DBM mRNA transcriptional response compared with noradrenaline (NA) depletion in Cu-deficient rat tissues. Normalised mRNA changes $v$. NA depletion were plotted for adrenal glands $(\bullet)$, medulla oblongata/pons $(\mathbf{\square})$, vasa deferentia $(\boldsymbol{\Lambda})$ and heart $(\bullet)$. A correlation coefficient of 0.2 was determined $(P>0.05)$.

plotted $v$. NA reduction (Fig. 7 (b)). The correlation coefficient for these four data pairs was calculated to be $0 \cdot 2$, and not statistically significant.

\section{Discussion}

The model for perinatal $\mathrm{Cu}$ deficiency in the present experiments produced rats that were severely deficient based on growth retardation, cardiac hypertrophy, and highly reduced brain and liver $\mathrm{Cu}$ levels. The results from adrenal, medulla oblongata/pons, vas deferens and heart strongly confirm and extend limited previous data that dietary $\mathrm{Cu}$ deficiency leads to an augmentation in DBM mRNA levels. Presently no data are available to evaluate DBM mRNA degradation in $\mathrm{Cu}-$ rats. Thus, we suggest that there is increased transcription of DBM following $\mathrm{Cu}$ deficiency. Past studies of $\mathrm{Cu}$ deficient rat adrenals showed that there was a significant elevation of DBM mRNA evaluated by Northern blots ${ }^{(18)}$. The same study showed an elevation in DBM mRNA in brain of $\mathrm{Cu}-$ female but not male rat pups. It is possible that multiple factors contribute to the up-regulation of DBM mRNA abundance as message levels are transcriptionally regulated by several factors including cAMP, glucocorticoids, bradykinin, nicotine and immobilisation stress ${ }^{(30)}$.

However, reduction of NA levels in $\mathrm{Cu}$ - tissues seemed like the most logical candidate for the increased transcription of DBM. Induction of rat adrenal DBM mRNA can be achieved by a treatment with reserpine, a drug that depletes catecholamines ${ }^{(19)}$. DBM activity and protein levels in the brain of rats were elevated when treated with reserpine, while catecholamines were lower ${ }^{(20)}$. Consistently lower NA levels in medulla oblongata/pons of $\mathrm{Cu}$-deficient rodents support the hypothesis that depleted NA levels drive the increased DBM mRNA transcription. However, our present results and past work show some inconsistencies in the hypothesis, particularly in adrenal tissue. Studies in older rats subjected to $\mathrm{Cu}$ deficiency after weaning found that rat adrenal NA was lower and DBM activity higher following $\mathrm{Cu}$ deficiency ${ }^{(18,31)}$. However, the present studies, as well as others, showed no significant reduction in NA content and yet increased DBM
mRNA $^{(18)}$. Additionally, Cu-deficient cattle showed an adrenal NA reduction but with no change in DBM activity ${ }^{(32)}$. Rat heart NA levels showed the greatest depletion of all the tissues studied in $\mathrm{Cu}-$ samples in the present studies, yet only a modest change in DBM mRNA and only when DBM copy number was normalised to two controls. The reduction in NA content and the DBM mRNA elevation in the four tissues studied in the present experiments were not statistically correlated. Thus, the mechanism for increased DBM mRNA transcription is still not well defined. One possibility is altered glucocorticoids since DBM transcription is augmented by glucocorticoids. This is an ideal candidate because glucocorticoids are elevated in both the adrenal glands and plasma of $\mathrm{Cu}-$ rats $^{(33)}$. However, $\mathrm{Cu}-$ mice also have higher DBM protein and activity, and perhaps mRNA levels. However, $\mathrm{Cu}-$ mice do not have higher glucocorticoids in plasma ${ }^{(34)}$. Higher DBM mRNA content in $\mathrm{Cu}$ - tissues could be due to increased transcript stability rather than enhanced synthesis. Future research is needed to fully understand the regulation of DBM following $\mathrm{Cu}$ deficiency.

However, our data clearly indicate that increased DBM mRNA abundance is associated with an increase in DBM protein. The present data confirm that in young $\mathrm{Cu}$-deficient rats increased adrenal DBM mRNA and increased DBM protein are evident ${ }^{(17,18)}$. Novel data report that DBM protein abundance in the medulla oblongata/pons by Western blot is higher in DBM protein in $\mathrm{Cu}-$ young male rats. Mouse adrenal and vas deferens samples also demonstrated higher DBM protein, demonstrating that mice responded in a similar manner to rats to $\mathrm{Cu}$ deprivation.

Higher DBM protein in $\mathrm{Cu}-$ animals is consistent with higher in vitro DBM activity and confirms similar changes in DBM activity and protein reported previously for adrenal glands from young rats ${ }^{(17)}$. The present results also show that higher DBM activity in vitro and higher DBM protein were evident in both adrenal and medulla/pons tissue of $\mathrm{Cu}-$ rats. The magnitude of change in both activity and protein are very similar (adrenal activity $2 \cdot 4$-fold $v$. protein 1.7 -fold change and medulla/pons activity 0.9 -fold $v$. protein $0 \cdot 7$-fold change). Though there was no significant difference 
in $\mathrm{Cu}-$ rats compared with $\mathrm{Cu}+$ rats for vas deferens for either DBM activity or protein levels, a trend of change in both was similar (activity $0 \cdot 2$-fold $v$. protein $0 \cdot 14$-fold change). Note that a very modest change for $\mathrm{CCS}$ in $\mathrm{Cu}-$ vas deferens was detected, suggesting a more marginal $\mathrm{Cu}$ deficiency in this tissue. There was an excellent correlation in $\mathrm{Cu}-$ rat tissues between augmented DBM protein and $\mathrm{DBM}$ in vitro activity in $\mathrm{Cu}-$ medulla/pons, adrenal glands and vas deferens of $0.98(P<0.05)$. This would suggest that the higher DBM activity observed in tissues from $\mathrm{Cu}-$ mammals is due to a higher abundance of DBM protein rather than changes in endogenous inhibitors or subtle kinetic differences observed previously ${ }^{(16,31)}$.

Despite higher DBM activity in vitro, catecholamine results suggest that DBM activity in vivo is lower in $\mathrm{Cu}-$ animals. As shown in the present study, NA is significantly lower in medulla/pons, vas deferens and heart of $\mathrm{Cu}-$ rats. DA levels were significantly higher in all four of the tissues studied in $\mathrm{Cu}-$ rats. The DA:NA ratio was significantly higher; approximately 2-fold greater in adrenals, medulla and vas deferens in $\mathrm{Cu}-$ rats compared with their controls. The ratio in heart was even higher, showing a 48-fold increase in $\mathrm{Cu}-$ rats. This is totally consistent with radiotracer studies done in $\mathrm{Cu}-$ rat heart suggesting that DBM activity in vivo was impaired by $\mathrm{Cu}$ deficiency ${ }^{(9)}$. Catecholamine changes in mouse heart and medulla oblongata/pons also respond in a similar manner to $\mathrm{Cu}$ deficiency ${ }^{(21)}$. Present and past data support the hypothesis that there is higher apo-DBM in tissues from $\mathrm{Cu}$-deficient mammals but function is limited by lower $\mathrm{Cu}$ availability. Data in the present studies were obtained from a severe restriction in dietary $\mathrm{Cu}$. Thus, the impact of more marginal $\mathrm{Cu}$ limitation to DBM function is unknown. Our work and that of others have indicated that DBM limitation can occur in a variety of mammals and that the response is both species and organ specific ${ }^{(35-37)}$.

The DA:NA ratio in serum can provide valuable information to the clinical community. Clinical and pathological features of Menkes' disease often reflect decreased activities of cuproenzymes, including DBM and others ${ }^{(38)}$. A significantly raised DA:NA ratio is a promising test for neonatal infants suspected of Menkes' disease ${ }^{(39)}$. Additionally, a higher DA:NA ratio was shown in $100 \%$ of the first six cases of DBM deficiency in humans ${ }^{(40)}$. Thus, the DA:NA ratio is a useful diagnostic tool for DBM limitation.

DBM is an important cuproenzyme. The low copy number of DBM mRNA and immunoblot data suggest that it is not a very abundant protein in the central nervous system. However, despite its low abundance, its function clearly is vital to the livelihood of animals, as demonstrated by the DBM knockout mouse studies $^{(8)}$. In humans, patients that have DBM deficiency have cardiovascular disorders and severe orthostatic hypotension. Regardless of the mechanisms for controlling DBM levels our data and others are congruent that DBM function in vivo requires adequate $\mathrm{Cu}$; thus DBM is a key cuproenzyme in mammals.

\section{Acknowledgements}

We thank Margaret Boderius, Joshua Pyatskowit and Anya Gybina for their excellent technical assistance. This research was supported by National Institutes of Health (NIH) grant HD-039708.
K. N. carried out most of the analytical work and J. P. designed the experiments. Both authors participated in writing the manuscript.

Neither of the authors has any conflicts of interest.

\section{References}

1. Smith RM (1983) Copper and the developing brain. In Neurobiology of the Trace Elements, pp. 1-40 [IE Dreosti and RM Smith, editors]. Clifton, NJ: Humana Press.

2. Prohaska JR (1987) Functions of trace elements in brain metabolism. Physiol Rev 67, 858-901.

3. Everson GJ, Tsai HC \& Wang TI (1967) Copper deficiency in the guinea pig. J Nutr 93, 533-540.

4. Danks DM, Campbell PE, Stevens BJ, et al. (1972) Menkes's kinky hair syndrome. An inherited defect in copper absorption with widespread effects. Pediatrics 50, 188-201.

5. Prohaska JR (2006) Copper. In Present Knowledge in Nutrition, pp. 458-470 [BA Bowman and RM Russell, editors]. Washington, DC: International Life Sciences Institute.

6. Friedman S \& Kaufman S (1965) 3,4-Dihydroxyphenylethylamine $\beta$-hydroxylase. Physical properties, copper content, and role of copper in the catalytic activity. J Biol Chem 240, 4763-4773.

7. Axelrod J (1972) Dopamine- $\beta$-hydroxylase: regulation of its synthesis and release from nerve terminals. Pharmacol Rev 24, 233-243.

8. Thomas SA, Matsumoto AM \& Palmiter RD (1995) Noradrenaline is essential for mouse fetal development. Nature 374, 643-646.

9. Missala K, Lloyd K, Gregoriads G, et al. (1967) Conversion of ${ }^{14} \mathrm{C}$-dopamine to cardiac ${ }^{14} \mathrm{C}$-noradrenaline in the copperdeficient rat. Eur J Pharmacol 1, 6-10.

10. Wise CD, Belluzzi JD \& Stein L (1977) Possible role of dopamine- $\beta$-hydroxylase in the regulation of norepinephrine biosynthesis in rat brain. Pharmacol Biochem Behav 7, 549-553.

11. Hunt DM (1974) Primary defect in copper transport underlies mottled mutants in the mouse. Nature 249, 852-854.

12. Prohaska JR \& Wells WW (1974) Copper deficiency in the developing rat brain: a possible model for Menkes' steely-hair disease. J Neurochem 23, 91-98.

13. Prohaska JR \& Bailey WR (1994) Regional specificity in alterations of rat brain copper and catecholamines following perinatal copper deficiency. J Neurochem 63, 1551-1557.

14. Prohaska JR \& Bailey WR (1993) Persistent regional changes in brain copper, cuproenzymes and catecholamines following perinatal copper deficiency in mice. J Nutr 123, 1226-1234.

15. Hunt DM (1977) Catecholamine biosynthesis and the activity of a number of copper-dependent enzymes in the copper deficient mottled mouse mutants. Comp Biochem Physiol C 57, 79-83.

16. Prohaska JR \& Smith TL (1982) Effect of dietary or genetic copper deficiency on brain catecholamines, trace metals and enzymes in mice and rats. $J$ Nutr 112, 1706-1717.

17. Prohaska JR \& Brokate B (2001) Dietary copper deficiency alters protein levels of rat dopamine- $\beta$-monooxygenase and tyrosine monooxygenase. Exp Biol Med 226, 199-207.

18. Prohaska JR \& Brokate B (1999) Copper deficiency alters rat dopamine $\beta$-monooxygenase mRNA and activity. J Nutr 129, 2147-2153.

19. McMahon A, Geertman R \& Sabban EL (1990) Rat dopamine $\beta$-hydroxylase: molecular cloning and characterization of the cDNA and regulation of the mRNA by reserpine. $J$ Neurosci Res 25, 395-404.

20. Reis DJ, Joh TH \& Ross RA (1975) Effects of reserpine on activities and amounts of tyrosine hydroxylase and 
dopamine- $\beta$-hydroxylase in catecholamine neuronal sytems in rat brain. J Pharmacol Exp Ther 193, 775-784.

21. Pyatskowit JW \& Prohaska JR (2007) Rodent brain and heart catecholamine levels are altered by different models of copper deficiency. Comp Biochem Physiol C 145, 275-281.

22. Markwell MA, Haas SM, Bieber LL, et al. (1978) A modification of the Lowry procedure to simplify protein determination in membrane and lipoprotein samples. Anal Biochem 87, 206-210.

23. Kato T, Kuzuya H \& Nagatsu T (1974) A simple and sensitive assay for dopamine- $\beta$-hydroxylase activity by dual-wavelength spectrophotometry. Biochem Med 10, 320-328.

24. Kibbe WA (2007) OligoCalc: an online oligonucleotide properties calculator. Nucleic Acids Res 35, W43-W46.

25. West EC \& Prohaska JR (2004) Cu,Zn-superoxide dismutase is lower and copper chaperone CCS is higher in erythrocytes of copper-deficient rats and mice. Exp Biol Med (Maywood) 229, 756-764.

26. Pyatskowit JW \& Prohaska JR (2005) L-Threo 3,4-dihydroxyphenylserine treatment during mouse perinatal and rat postnatal development does not alter the impact of dietary copper deficiency. Nutr Neurosci 8, 173-181.

27. Teman PT \& Prohaska JR (1999) Copper-deficient rats have altered plasma dihydroxyphenylacetic acid and spleen catecholamine levels. Nutr Neurosci 2, 103-111.

28. Wallace EF, Krantz MJ \& Lovenberg W (1973) Dopamine- $\beta$ hydroxylase: a tetrameric glycoprotein. Proc Natl Acad Sci U $S$ A 70, 2253-2255.

29. Prohaska JR, Broderius M \& Brokate B (2003) Metallochaperone for $\mathrm{Cu}, \mathrm{Zn}$-superoxide dismutase (CCS) protein but not mRNA is higher in organs from copper-deficient mice and rats. Arch Biochem Biophys 417, 227-234.
30. McMahon A \& Sabban EL (1992) Regulation of expression of dopamine $\beta$-hydroxylase in PC12 cells by glucocorticoids and cyclic AMP analogues. J Neurochem 59, 2040-2047.

31. Hesketh JE (1981) The effect of nutritional copper deprivation on the catecholamine content and dopamine- $\beta$-hydroxylase activity of rat and cattle adrenal glands. Gen Pharmacol 12, 445-449.

32. Hesketh JE (1980) Catecholamine synthesis in the adrenal medulla of cattle deficient in copper. Biochem Soc Trans 8, 342.

33. Fields M, Lewis CG \& Lure MD (1991) The role of the adrenals in copper deficiency. Metabolism 40, 540-544.

34. Prohaska JR, Downing SW \& Lukasewycz OA (1983) Chronic dietary copper deficiency alters biochemical and morphological properties of mouse lymphoid tissues. J Nutr 113, $1583-1590$.

35. O'Dell BL, Smith RM \& King RA (1976) Effect of copper status on brain neurotransmitter metabolism in the lamb. J Neurochem 26, 451-455.

36. Prohaska JR, Bailey WR, Gross AM, et al. (1990) Effect of dietary copper deficiency on distribution of dopamine and norepinephrine in mice and rats. J Nutr Biochem 1, 149-154.

37. Schoenemann HM, Failla ML \& Rosebrough RW (1990) Cardiac and splenic levels of norepinephrine and dopamine in copper deficient pigs and rats. Comp Biochem Physiol C 97, 387-391.

38. Kaler SG (1994) Menkes disease. Adv Pediatr 41, 263-304.

39. Kaler SG, Holmes CS, Goldstein DS, et al. (2008) Neonatal diagnosis and treatment of Menkes disease. $N$ Engl J Med 358, 605-614

40. Robertson D, Haile V, Perry SE, et al. (1991) Dopamine $\beta$-hydroxylase deficiency. A genetic disorder of cardiovascular regulation. Hypertension 18, 1-8. 